\title{
Tolerability of gefitinib in patients receiving treatment in everyday clinical practice
}

\author{
N van Zandwijk ${ }^{*, 1}$ \\ 'Department of Thoracic Oncology and Biometrics, The Netherlands Cancer Institute, Amsterdam, The Netherlands
}

\begin{abstract}
Gefitinib ('Iressa', ZDI839), an epidermal growth factor receptor tyrosine kinase inhibitor, has recently been approved in several countries for use in advanced or metastatic non-small-cell lung cancer (NSCLC). In contrast to chemotherapies, which are generally used at or near their maximum-tolerated dose (MTD), gefitinib is used at an optimal biological dose $\left(250 \mathrm{mg} \mathrm{day}^{-1}\right)$, which is substantially below its MTD, minimising the risk of adverse events without compromising efficacy. Tolerability data from the compassionate use of gefitinib in the 'Iressa' Expanded Access Programme support the favourable safety profile of the agent reported in Phase I and II trials. In both settings, the majority of adverse drug reactions were mild/moderate and consisted mainly of grade I/2 diarrhoea and skin rash. Although skin rash has been suggested to predict response to gefitinib, available data do not support this hypothesis. Overall, these tolerability data demonstrate that gefitinib has a relatively benign side-effect profile and is a well-tolerated treatment option for patients with previously treated NCSLC, who currently have few alternatives.

British Journal of Cancer (2003) 89 (Suppl 2), S9-SI4. doi:I0.I038/sj.bjc.660I477 www.bjcancer.com

(c) 2003 Cancer Research UK
\end{abstract}

Keywords: gefitinib ('Iressa', ZD I839); EGFR-TKI; NSCLC; side effects; tolerability; risk:benefit

In advanced non-small-cell lung cancer (NSCLC) platinum doublets are regarded standard for palliative therapy for patients of performance status (PS) $0-1$, but their palliative use is hindered by the toxicity elicited by these combinations. Cisplatin induces nausea and vomiting in a majority of patients and is also associated with nephrotoxicity, neurotoxicity, ototoxicity and anaemia (BC Cancer Agency, 2003; British National Formulary, 2003). In a significant number of cases these toxic effects result in dose reduction or withdrawal of cisplatin and transfer of the patient to an alternative treatment. Less fit patients $(P S \geqslant 2)$ with NSCLC are advised to avoid platinum-based treatments (Schiller et al, 2002) and frequently receive single-agent chemotherapies first line. Gemcitabine, vinorelbine and the taxanes are being used as single agents for this indication and, although much better tolerated than in combination with platinum agents, their use may also be complicated by side effects.

The approved second-line chemotherapy option for patients of PS 0-1 who either cannot tolerate or who fail first-line platinumbased treatment is docetaxel. The administration of docetaxel is associated with prominent side effects such as neutropenia, alopecia, leucocytopenia and nail changes (BC Cancer Agency, 2003; British National Formulary, 2003). Patients receiving chemotherapies need to be closely monitored to avoid complications and discontinuation of treatment.

The toxicity issues that surround the use of standard chemotherapy highlight the clinical need for novel anticancer agents that have a mode of action that is different from the indiscriminate action of cytotoxic chemotherapies. It is anticipated that such agents will combine targeted antitumour activity with improved tolerability over cytotoxic agents. Gefitinib

*Correspondence: Dr Nico van Zandwijk; E-mail: n.v.zandwijk@nki.nl
('Iressa', ZD1839), an epidermal growth factor receptor tyrosine kinase inhibitor (EGFR-TKI), is an example of a targeted agent that has demonstrated favourable tolerability and durable antitumour activity in clinical trials in patients with advanced NSCLC (Fukuoka et al, 2003; Kris et al, 2003). The assessment of the gefitinib safety data reported via the 'Iressa' Clinical Experience (ICE) meeting, held in June 2003 in Madrid, Spain, provided valuable insight into the tolerability of the agent in everyday clinical practice. This article summarises the safety and tolerability findings from this experience and assesses how they compare with the safety and tolerability conclusions from the pivotal Phase II studies (Fukuoka et al, 2003; Kris et al, 2003). We also explore the biological basis of the good tolerability of gefitinib and discuss the impact of the agent's side-effect profile on its risk:benefit ratio.

\section{TOLERABILITY OBSERVED IN IDEAL TRIALS}

The tolerability of gefitinib 250 or $500 \mathrm{mg} \mathrm{day}^{-1}$ was assessed in two randomised, double-blind trials in 425 pretreated patients with advanced or metastatic NSCLC. The 'Iressa' Dose Evaluation in Advanced Lung cancer (IDEAL) 1 trial enrolled 209 patients from centres in Europe, Australia, South Africa and Japan, all of whom had received $\leqslant 2$ prior regimens, including one that was platinum based (Fukuoka et al, 2003). IDEAL 2 recruited 216 patients in the USA, who had previously received $\geqslant 2$ chemotherapy regimens, including a platinum compound and docetaxel, used either together or as separate regimens (Kris et al, 2003). The safety profile of gefitinib demonstrated in these trials was consistent with that reported in the Phase I trials, and no unexpected adverse drug reactions (ADRs) were observed. The most common ADRs were mild (grade 1 or 2) and consisted mainly of diarrhoea and skin 
rash, which typically presented during the first month of treatment. Although the profile of grade $1 / 2$ ADRs was similar for both doses, grade 1/2 ADRs were more frequently reported with gefitinib $500 \mathrm{mg} \mathrm{day}^{-1}$. For example in IDEAL 2, grade $1 / 2$ diarrhoea was reported in $56 \%$ of patients receiving gefitinib $250 \mathrm{mg} \mathrm{day}^{-1}$ and $69 \%$ of those receiving $500 \mathrm{mg} \mathrm{day}^{-1}$. Grade $3 / 4$ ADRs were also dose related. In both trials, a higher incidence of grade 3/4 ADRs was reported in patients receiving gefitinib $500 \mathrm{mg} \mathrm{day}^{-1}$ than in those receiving the lower dose (23.6 vs $7.8 \%$, respectively). Most of the ADRs were manageable and noncumulative. In both trials, few patients discontinued gefitinib due to ADRs ( $1.5 \%$ for $250 \mathrm{mg} \mathrm{day}^{-1}$ and $6.8 \%$ for $500 \mathrm{mg} \mathrm{day}^{-1}$ ). These data show that, although both doses of gefitinib were generally well tolerated, the $250 \mathrm{mg}$ day $^{-1}$ dose was better tolerated overall. As efficacy data from the IDEAL trials showed that both doses had similar antitumour activity, these data support $250 \mathrm{mg}^{-1 a y}{ }^{-1}$ as the recommended dose for advanced NSCLC because it provides effective clinical benefit and retains favourable tolerability.

\section{TOLERABILITY OF GEFITINIB IN EVERYDAY CLINICAL PRACTICE}

Centres participating in the 'Iressa' Expanded Access Programme (EAP) have administered gefitinib $250 \mathrm{mg} \mathrm{day}^{-1}$ to patients with advanced NSCLC on a compassionate basis. The Netherlands Cancer Institute case series is one of the largest groups of patients ( $n=100)$ from a single institution for which EAP experience is available (Haringhuizen, ICE abs; Haringhuizen et al, 2003). (See appendix for ICE abstracts). Results from this case series were discussed in detail at the ICE meeting. In this case series, $>50 \%$ of patients presented with adenocarcinoma and stage IV disease (Table 1). A substantial proportion of patients (approximately $33 \%)$ were unfit for chemotherapy and had PS $\geqslant 2$. The majority of patients $(62 \%)$ had received one prior chemotherapy regimen and, of these, $94.1 \%$ had received platinum-based treatment. Consistent with the tolerability profile of gefitinib in clinical trials, the majority of adverse events experienced by these patients in this EAP study were mild (grade 1/2) and the most common grade 1/2 adverse effects were skin rash, diarrhoea and desquamation/ itching $(34.0,21.8$ and $21.8 \%$ of patients, respectively) (Haringhuizen, ICE abs). Grade 3/4 adverse events were rare and linked to skin and gastrointestinal adverse events (Tables 2 and 3). Gefitinib was well tolerated by most patients and $<6 \%$ of patients withdrew/discontinued treatment due to adverse events.

A further six case series, each consisting of $>45$ patients, were also submitted to the ICE meeting (Gridelli [a], ICE abs;

Table I The Netherlands Cancer Institute EAP experience - patient demography (Haringhuizen et al, 2003)

Patients, $n$, evaluable/nonevaluable
Male/female, $n$
WHO/ECOG performance status ${ }^{\mathrm{a}}$ 0/I/2/3/4
Histology (\%)
Adenocarcinoma
Squamous-cell carcinoma
Large-cell carcinoma
Bronchioalveolar carcinoma
Stage III//V
Previous chemotherapy, $n$
Chemonaive
First line
Second line
Third line
Fourth line

$92 / 8$

$48 / 44$ $9 / 37 / 22 / 7 / 1$

\section{1}

20

15

WHO, World Health Organization; ECOG, Eastern Cooperative Oncology Group. ${ }^{a}$ Not recorded in 16 patients.
Table 2 The Netherlands Cancer Institute EAP experience - adverse events $(n=92)$ (Haringhuizen, ICE abs)

\begin{tabular}{lcccc}
\hline & $\begin{array}{c}\text { Grade I } \\
\text { (\%) }\end{array}$ & $\begin{array}{c}\text { Grade 2 } \\
\text { (\%) }\end{array}$ & $\begin{array}{c}\text { Grade 3 } \\
\text { (\%) }\end{array}$ & $\begin{array}{c}\text { Grade 4 } \\
\text { (\%) }\end{array}$ \\
\hline Diarrhoea & 19.6 & 2.2 & 1.1 & 1.1 \\
Skin rash & 19.6 & 14.4 & 1.1 & - \\
Desquamation/itching & 20.7 & 1.1 & 1.1 & - \\
Nausea/vomiting & 14.1 & 4.4 & - & - \\
Anorexia & 13.0 & 10.9 & - & - \\
Liver-enzyme elevation & 3.3 & 2.2 & - & - \\
\hline
\end{tabular}

Gridelli [b], ICE abs; Bianco, ICE abs; Cortes-Funes, ICE abs; Chioni, ICE abs; de Braud, ICE abs). Their safety findings are consistent with tolerability results from The Netherlands Cancer Institute case series (Haringhuizen, ICE abs) and are also summarised in Table 3.

Overall, data from all these case series (Haringhuizen, ICE abs; Gridelli [a], ICE abs; Gridelli [b], ICE abs; Bianco, ICE abs; CortesFunes, ICE abs; Chioni, ICE abs; de Braud, ICE abs) (total $n=$ 521) show that gefitinib is well tolerated by pretreated patients with NSCLC in everyday clinical practice. Most of the common adverse events were mild/moderate and the majority were grade $1 / 2$ diarrhoea and skin rash (Figures 1 and 2). Grade 3/4 adverse events were reported rarely (Table 3 ). Similar findings concerning the good tolerability of gefitinib in everyday clinical practice have also been reported by other large EAP case series in both adult (López Martin et al, 2003; Park et al, 2003) and elderly patients (Soto Parra et al, 2003).

Analysis of the safety data from gefitinib-treated patients has shown that unexpected or unusual adverse events with gefitinib are rare. One such rare event that has been recently featured in the media is interstitial lung disease (ILD), which was stimulated by the publication of a Japanese report of four patients who experienced interstitial pneumonia while receiving gefitinib (Inoue et al, 2003). ILD is not an uncommon event in patients who receive therapy for NSCLC and it may occur as a sign of progression of the disease itself (metastatic/lymphomytic spread) or as a consequence of its treatment. Standard lung cancer treatments, such as chemotherapy and radiotherapy, are able to elicit ILD, with incidences of $10 \%$ and higher reported (Chen et al, 2000; Thomas et al, 2000; Rebattu et al, 2001; Willner et al, 2001; Bhatia et al, 2002). ILD was not reported with gefitinib $250 \mathrm{mg} \mathrm{day}^{-1}$ in the IDEAL trials and has been reported rarely during its wider use in clinical practice. Four cases of ILD were reported at the ICE meeting (Haringhuizen, ICE abs; Overbeck and Griesinger, ICE abs; Cortes-Funes, ICE abs; Gervais, ICE abs). Analysis in over 92000 patients worldwide, who have received gefitinib to date (September 2003), has shown that the incidence of ILD-type events was less than $1 \%$ (Forsythe and Faulkner, 2003). The frequency of ILD-type events in Japanese patients $(1.9 \%)$ appears to be higher than in the rest of the world $(0.3 \%)$; the reason for this is unknown, although it may be related to population or environmental differences or differences in clinical practice. Of interest, this observed ethnic difference in reporting rates does not extend to other South East Asian countries (eg China, Hong Kong, Korea, Malaysia, Philippines, Singapore, Taiwan and Thailand), where the frequency of reporting ILD is comparable to that in the rest of the world $(0.3 \%)$. Further investigations to clarify the reasons for such an ethnic stratification in ILD incidence following treatment are underway.

Overall, these safety data from the EAP are consistent with the findings from the IDEAL trials, and confirm that gefitinib is a welltolerated anticancer agent. Most of its side effects are mild and unusual or unexpected side effects are rare. 
Table 3 Safety and tolerability observations from eight case series $>45$ patients ${ }^{a}$ with advanced NSCLC who received gefitinib compassionately through the gefitinib EAP

\begin{tabular}{|c|c|c|c|c|c|}
\hline Author & $\begin{array}{l}\text { Patients treated } \\
\text { (evaluable), } n\end{array}$ & $\begin{array}{l}\text { Median age } \\
\text { and/or } \\
\text { range (years) }\end{array}$ & $\begin{array}{l}\text { Histology/disease } \\
\text { stage }\end{array}$ & $\begin{array}{l}\text { Prior treatment } \\
\text { experience }\end{array}$ & $\begin{array}{l}\text { Overall } \\
\text { assessment of gefitinib tolerability by } \\
\text { author }\end{array}$ \\
\hline $\begin{array}{l}\text { Haringhuizen, ICE } \\
\text { abs }\end{array}$ & $92(92)$ & $33-76$ & $\begin{array}{l}62 \% \text { Adenocarcinoma } \\
14 \% \text { Stage III } \\
86 \% \text { Stage IV }\end{array}$ & $\begin{array}{l}92 \% \geqslant \text { first-line } \\
\text { chemotherapy }\end{array}$ & $\begin{array}{l}\text { Good tolerability. Most side effects were mild. Most } \\
\text { frequent side effects were grade I/2 skin rash, } \\
\text { diarrhoea and desquamation/itching ( } 34.0,21.8 \text { and } \\
21.8 \% \text { of patients, respectively). ILD without } \\
\text { symptoms observed in one (I\%) patient, which } \\
\text { resolved during treatment }\end{array}$ \\
\hline Bianco, ICE abs & $\begin{array}{l}49(49) \\
P S \leqslant 2\end{array}$ & $59(29-80)$ & $\begin{array}{l}49 \% \text { Adenocarcinoma } \\
47 \% \text { Squamous-cell } \\
2 \% \text { Bronchioalveolar } \\
2 \% \text { Large-cell } \\
16 \% \text { Stage IIlb } \\
84 \% \text { Stage IV }\end{array}$ & $\begin{array}{l}100 \% \geqslant \text { second- } \\
\text { line chemotherapy }\end{array}$ & $\begin{array}{l}\text { Tolerability was excellent, two ( } 4 \% \text { ) patients } \\
\text { experienced mild, drug-related skin rash }\end{array}$ \\
\hline $\begin{array}{l}\text { Cortes-Funes, ICE } \\
\text { abs }\end{array}$ & $113(113)$ & $61(36-83)$ & $\begin{array}{l}41 \% \text { Adenocarcinoma } \\
40 \% \text { Squamous-cell } \\
15 \% \text { large-cell } \\
4 \% \text { Other } \\
30 \% \text { Stage I-Ila } \\
70 \% \text { Stage IIIb-IV }\end{array}$ & $\begin{array}{l}79 \% \geqslant \text { second-line } \\
\text { chemotherapy }\end{array}$ & $\begin{array}{l}\text { Well tolerated. Most side effects were mild/ } \\
\text { moderate. The most frequent adverse events were } \\
\text { grade } 1 / 2 \text { skin toxicity } 42.5 \% \text { patients }(3.5 \% \text { grade } \\
3 / 4) \text {, diarrhoea } 21.2 \% \text { patients }(0.9 \% \text { grade } 3 / 4 \text { ) and } \\
20.4 \% \text { asthenia }(5.3 \% \text { grade } 3 / 4) \text {. Other adverse } \\
\text { events included nausea and vomiting (grade } 1 / 2 \\
\text { 10.6\%; grade } 3 / 40.9 \%) \text {, anorexia }(9.7 \% \text {; } 3.5 \%) \text {, } \\
\text { neurological toxicity ( } 9.7 \% \text {; } 1.8 \% \text { ) and pulmonary } \\
\text { toxicity ( } 0.9 \% ; 0.9 \%)\end{array}$ \\
\hline de Braud, ICE abs & $79(67)$ & $56(3 \mid-77)$ & $\begin{array}{l}65 \% \text { Adenocarcinoma } \\
18 \% \text { Squamous-cell } \\
4 \% \text { Bronchioalveolar } \\
5 \% \text { Other } \\
\text { Locally advanced or } \\
\text { metastatic disease }\end{array}$ & $\begin{array}{l}\text { Median number of } \\
\text { chemotherapy } \\
\text { regimens }=2 \\
\text { range }(1-6)\end{array}$ & $\begin{array}{l}\text { Well tolerated. Most side effects were mild/ } \\
\text { moderate grade I/2 skin reactions ( } 30 \%) \text {, diarrhoea } \\
\text { ( } 9 \% \text { ) and nausea ( } 4 \% \text { ). Grade } 3 / 4 \text { skin reactions } \\
\text { occurred in } 2 \% \text { of patients }\end{array}$ \\
\hline
\end{tabular}

${ }^{a}$ Case series were discussed at the 'Iressa' Clinical Experience (ICE) meeting and provided information on safety and tolerability. ILD = interstitial lung disease; EHP = Expanded Access Programme; NSCLC $=$ non-small-cell lung cancer.

\section{BIOLOGICAL BASIS OF GOOD TOLERABILITY OF GEFITINIB}

Standard chemotherapeutic agents are cytotoxic drugs that kill dividing cells so their antitumour activity and toxic effects are generally seen within the same dose range. The dose of chemotherapy drugs selected for clinical use is usually the maximum-tolerated dose (MTD) (Figure 3A). In contrast, as gefitinib is used at an optimal biological dose (OBD), which is substantially below its
MTD, the risk of adverse events is minimised without compromising efficacy (Figure 3B) (Rowinsky, 2000). The pharmacodynamic differences between biologically targeted agents and standard chemotherapeutics may explain why gefitinib has a more favourable side-effect profile than some traditional chemotherapies.

Clinical evidence from Phase I and II trials has demonstrated that gefitinib has a wide therapeutic margin that enables it to be used at a dose that provides the optimal balance of efficacy and 


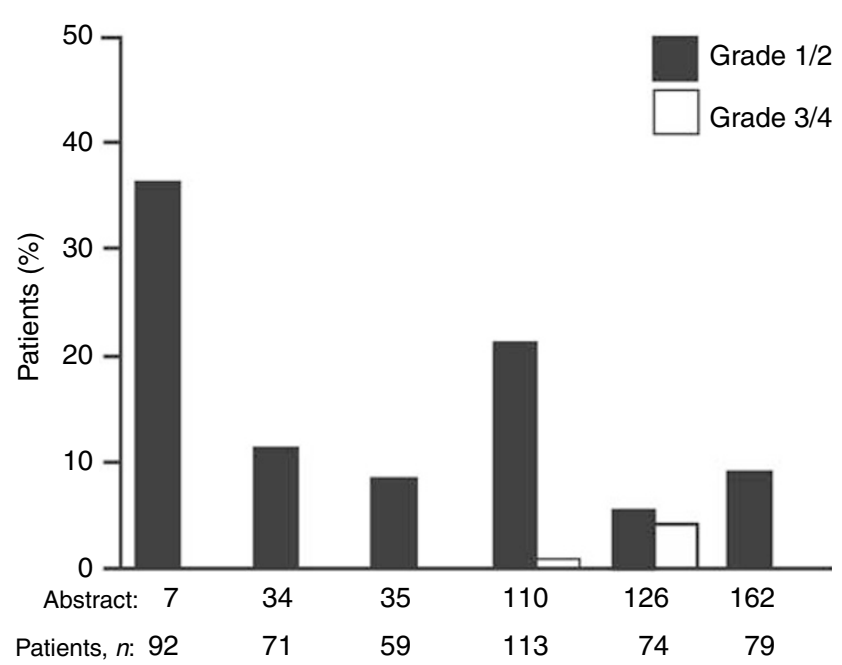

Figure I Incidence of diarrhoea in six case series with $\geqslant 45$ patients from the ICE meeting that reported diarrhoea as a commonly occurring adverse event (Haringhuizen, ICE abs; Gridelli [a], ICE abs; Gridelli [b], ICE abs; Cortes-Funes, ICE abs; Chioni, ICE abs; de Braud, ICE abs)

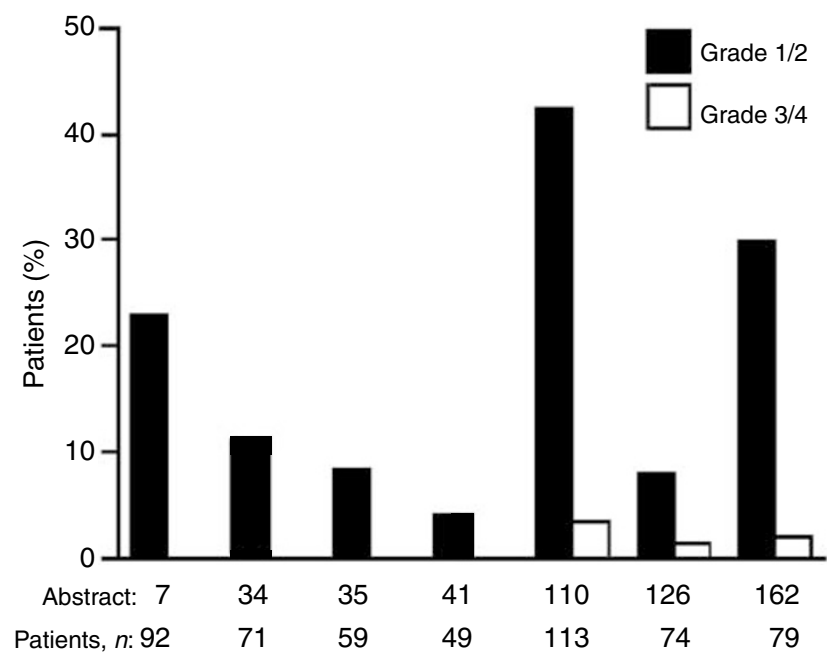

Figure 2 Incidence of skin rash in seven case series with $\geqslant 45$ patients from the ICE meeting that reported skin rash as a commonly occurring adverse event (Haringhuizen, ICE abs; Gridelli [a], ICE abs; Gridelli [b], ICE abs; Bianco, ICE abs; Cortes-Funes, ICE abs; Chioni, ICE abs; de Braud, ICE abs)

tolerability. Initial evidence relating to the OBD of gefitinib came from Phase I clinical trials, where the data suggested that gefitinib had biological and clinical activity over the complete dose range studied (150-1000 $\mathrm{mg} \mathrm{day}^{-1}$ ) (Baselga et al, 2002; Herbst et al, 2002; Ranson et al, 2002; Nakagawa et al, 2003). On the basis of these data, two dose levels ( 250 and $500 \mathrm{mg} \mathrm{day}^{-1}$ ) were selected for Phase II/III studies, which were both significantly below the $\geqslant 700 \mathrm{mg} \mathrm{day}^{-1}$ MTD of gefitinib identified in Phase I clinical trials (Ranson et al, 2002). Gefitinib $250 \mathrm{mg} \mathrm{day}^{-1}$ was chosen because it was above the lowest dose shown to effect antitumour activity and gefitinib $500 \mathrm{mg} \mathrm{day}^{-1}$ selected as it was the highest dose that was well tolerated by most patients during long-term use. Gefitinib was evaluated at these dose levels in the IDEAL trials and the data showed that both gefitinib 250 and $500 \mathrm{mg} \mathrm{day}^{-1}$ provided similar efficacy, but that the higher dose was associated with a higher frequency and severity of ADRs (Fukuoka et al, 2003; Kris et al, 2003) (Figure 4).

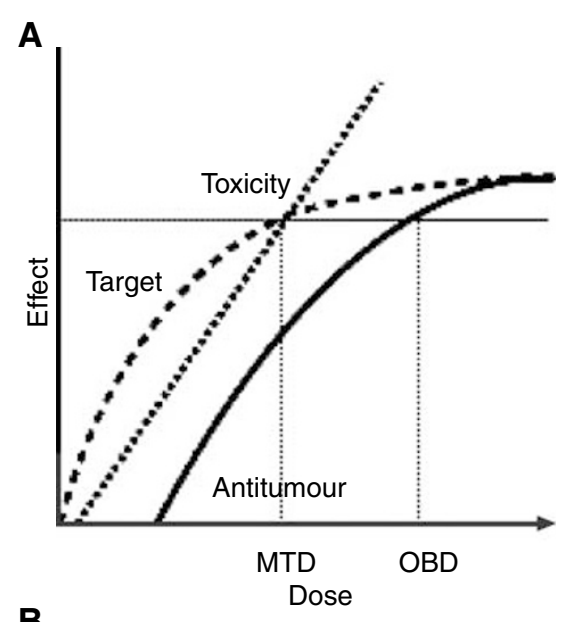

B

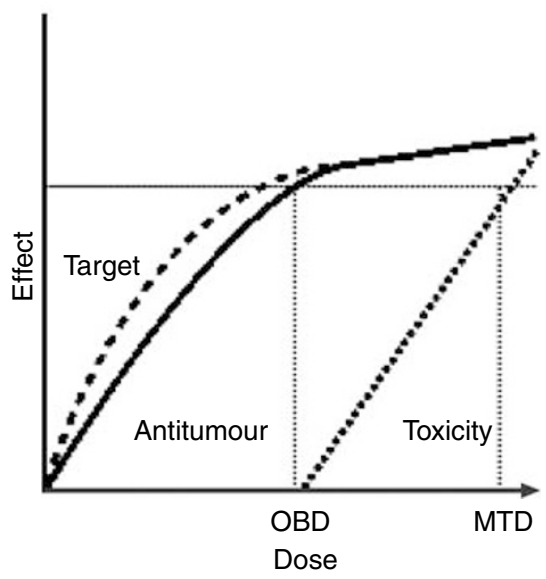

MTD, maximum-tolerated dose OBD, optimal biological dose

Figure 3 Idealised curves reflecting molecular target effects, antitumour effects and toxicity as functions for (A) a typical cytotoxic agent whose toxicity occurs at roughly the same dose as target effects and (B) a hypothetical target-based antiproliferative agent whose target effects occur at lower doses than toxic effects. Adapted with permission from: Rowinsky EK (2000)

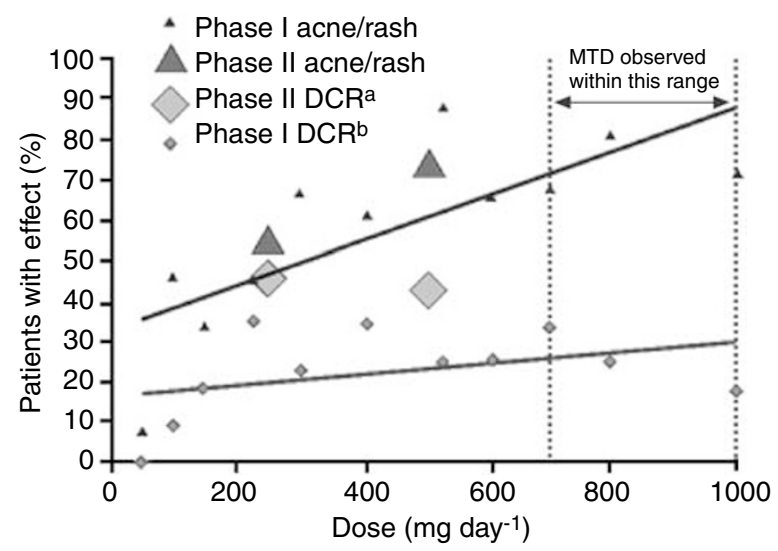

apatients who respond or are clinically stable for $\geqslant 2$ months bPatients who respond or are clinically stable for $\geqslant 3$ months MTD, maximum-tolerated dose; DCR, disease control rate

Figure 4 Relationship between gefitinib dose, objective response and rash. From: Herbst R (2003), with permission from Elsevier 


\section{Skin rash and response}

As detailed above, mild skin rash is one of the most common ADRs associated with gefitinib. Recent reports have suggested that skin rash may predict clinical response to EGFR inhibitors. These assumptions are based on the observations that most patients with a response, stable disease or long-term survival have a skin rash, there is a higher incidence of rash among responders than nonresponders and that survival end points are longer in patients with rash. These observations have been reported with the EGFR inhibitors gefitinib (Cohen et al, 2003; Janne et al, 2003), erlotinib (Perez-Soler et al, 2001) and cetuximab (Kies et al, 2002). However, as patients with an objective response generally receive treatment for longer than those with disease progression, it might be expected that there would be a higher incidence of rash in these patients, suggesting that simultaneous occurrence of rash and response may be coincidental. It is conceivable, however, that early-onset rash (one which develops within 14-28 days) may be more relevant to response than rash that develops later in treatment. To investigate this further, a retrospective analysis examined the onset of early rash in patients with NSCLC who received gefitinib in IDEAL 2 and survived $\geqslant 28$ days of treatment. Multivariate analysis found no statistically significant association between early-onset skin toxicity (skin rash, pruritus, acne, dry skin) and objective response rate with either gefitinib 250 or $500 \mathrm{mg} \mathrm{day}^{-1}$. By day 14, eight of the 12 patients $(67 \%)$ who ultimately responded to gefitinib $250 \mathrm{mg} \mathrm{day}^{-1}$ had not developed any skin toxicity and by day 28 , three of the $12(25 \%)$ responders had not yet developed skin toxicity. Retrospective assessment of incidence of skin rash in both IDEAL trials has shown that nine of the 31 responders $(29 \%)$ to gefitinib $250 \mathrm{mgday}^{-1}$ did not experience skin rash at any time during treatment. Data from the gefitinib clinical trial programme have also shown that the incidence of skin rash, but not response, increases with increasing dose. In Phase I trials, in which gefitinib was tested over the dose range $150-1000 \mathrm{mg} \mathrm{day}^{-1}$, the incidence of rash correlated with escalating dose: from approximately $30 \%$ at $150 \mathrm{mg} \mathrm{day}^{-1}$ to approximately $80 \%$ at $1000 \mathrm{mg} \mathrm{day}^{-1}$ (Baselga et al, 2002; Herbst et al, 2002; Ranson et al, 2002; Nakagawa et al, 2003). Correlation between dose and skin rash was also evident in the Phase II IDEAL trials, where gefitinib $500 \mathrm{mg} \mathrm{day}^{-1}$ was associated with a higher incidence of rash but similar objective response rates and survival as the $250 \mathrm{mg} \mathrm{day}^{-1}$ dose.

These clinical data are supported by results from a study that analysed the pharmacodynamic effects of gefitinib in paired skin biopsies from patients who were receiving gefitinib $150-$ $1000 \mathrm{mg} \mathrm{day}^{-1}$ in Phase I trials (Albanell et al, 2002). The study found that gefitinib inhibited skin EGFR activation at all doses $\geqslant 150 \mathrm{mg} \mathrm{day}^{-1}$ and that there was no significant correlation between pharmacodynamic effects and skin toxicity.

Together, these clinical and experimental data do not support the hypothesis that skin toxicity predicts response to gefitinib.

\section{DISCUSSION}

It is encouraging that the favourable safety profile of gefitinib demonstrated in Phase I and II trials is consistent with that observed in everyday settings. Data from clinical trials and the EAP indicate that gefitinib is well tolerated by patients with advanced or metastatic NSCLC. The majority of ADRs associated with gefitinib are mild in nature and those most commonly reported are grade 1/2 diarrhoea and skin reactions. Although skin rash has been hypothesised to be a potential prognostic factor for response to EGFR inhibitors, the lack of correlation between skin rash and clinical benefit over a wide range of gefitinib doses $\left(150-1000 \mathrm{mg} \mathrm{day}^{-1}\right)$ in clinical trials demonstrates that it should not be used to direct treatment with gefitinib. The analysis of trial data has shown that not all responders to gefitinib experience skin rash. Hence, it would seem inappropriate to use skin rash as a surrogate marker of response to gefitinib as it would deny patients who do not experience skin rash the potential to obtain benefit from treatment. Until more predictive molecular markers are identified, symptom improvement should be used as a meaningful prognostic indicator of the clinical benefit of gefitinib.

The relatively benign side-effect profile of gefitinib is very different from the safety profile of standard chemotherapy agents, with which patients frequently experience serious ADRs such as haematological toxicity, neurotoxicity, and nausea and vomiting. Often the severity of these ADRs requires medical intervention and in some cases patients will need to be hospitalised for management of toxicity caused by chemotherapy. In contrast, use of gefitinib in clinical trials and in everyday clinical practice shows that grade 3/4 ADRs and unexpected/unusual ADRs are rare. In addition, the findings show that the agent is not associated with cytotoxic ADRs and any nausea and vomiting experienced by patients during gefitinib treatment is generally mild to moderate.

It is suggested that pharmacodynamic differences between gefitinib and cytotoxic chemotherapies may account for gefitinib's favourable tolerability. Traditional chemotherapies are used at their MTD to exert their maximum efficacy but at the cost of a high level of toxicity and poor tolerability. In contrast, well-designed randomised dose-finding trials in NSCLC have demonstrated that gefitinib doses higher than $250 \mathrm{mg} \mathrm{day}^{-1}$ do not give a better response and cause increased toxicity. Hence, gefitinib is recommended to be used at an OBD $\left(250 \mathrm{mg} \mathrm{day}^{-1}\right)$ that provides clinical benefit while retaining favourable tolerability.

The contrasting safety profiles of gefitinib and chemotherapy highlight the important new approach that gefitinib brings to NSCLC. In addition to providing clinical benefit to a subset of patients with advanced or metastatic disease, the favourable safety profile of gefitinib avoids toxic reactions commonly seen with standard chemotherapy.

\section{REFERENCES}

Albanell J, Rojo F, Averbuch S, Feyereislova A, Mascaro JM, Herbst R, LoRusso P, Rischin D, Sauleda S, Gee J, Nicholson RI, Baselga J (2002) Pharmacodynamic studies of the epidermal growth factor receptor inhibitor ZD1839 in skin from cancer patients: histopathologic and molecular consequences of receptor inhibition. J Clin Oncol 20: 110-124

Baselga J, Rischin D, Ranson M, Calvert H, Raymond E, Kieback DG, Kaye SB, Gianni L, Harris A, Bjork T, Averbuch SD, Feyereislova A, Swaisland H, Rojo F, Albanell J (2002) Phase I safety, pharmacokinetic, and pharmacodynamic trial of ZD1839, a selective oral epidermal growth factor receptor tyrosine kinase inhibitor, in patients with five selected solid tumor types. J Clin Oncol 20: 4292-4302

BC Cancer Agency (2003) http://www.bccancer.bc.ca.default.htm
Bhatia S, Hanna N, Ansari R, Pletcher W, Einhorn L, Ng E, Sandler A (2002) A phase II study of weekly gemcitabine and paclitaxel in patients with previously untreated stage IIIb and IV non-small cell lung cancer. Lung Cancer 38: $73-77$

British National Formulary (2003) BNF 46. http://www.bnf.org

Chen Y-M, Perng R-P, Yang K-Y, Liu T-W, Tsai C-M, Ming-Liu J, WhangPeng J (2000) A multicenter phase II trial of vinorelbine plus gemcitabine in previously untreated inoperable (stage IIIB/IV) non-small cell lung cancer. Chest 117: $1583-1589$

Cohen EEW, Rosen F, Stadler WM, Recant W, Stanson K, Huo D, Vokes EE (2003) Phase II trial of ZD1839 in recurrent or metastatic squamous cell carcinoma of the head and neck. J Clin Oncol 21: 1980-1987 
Forsythe B, Faulkner K (2003) Safety and tolerability of gefitinib ('Iressa', ZD1839) in advanced NSCLC: overview of clinical experience. Poster presented at the ERS 13th Annual Congress. Vienna, Austria September 27 - October 1. Poster number P327

Fukuoka M, Yano S, Giaccone G, Tamura T, Nakagawa K, Douillard J-Y, Nishiwaki Y, Vansteenkiste J, Kudoh S, Rischin D, Eek R, Horai T, Noda K, Takata I, Smit E, Averbuch S, Macleod A, Feyereislova A, Dong R-P, Baselga J (2003) Multi-institutional randomized phase II trial of gefitinib for previously treated patients with advanced non-small-cell lung cancer. J Clin Oncol 21: 2237-2246

Haringhuizen A, Vaessen HFR, Baas P, van Zandwijk N (2003) Gefitinib ('Iressa', ZD1839) as a last option for patients with recurrent non-smallcell lung cancer (NSCLC). Poster presented at the 10th WCLC. Vancouver, Canada August 10-14. Poster number P-617

Herbst R (2003) Targeting the epidermal growth factor receptor: prognostic and clinical implications. EJC Suppl 1: 9-15

Herbst RS, Maddox AM, Rothenberg ML, Small EJ, Rubin EH, Baselga J, Rojo F, Hong WK, Swaisland H, Averbuch SD, Ochs J, LoRusso PM (2002) Selective oral epidermal growth factor receptor tyrosine kinase inhibitor ZD1839 is generally well-tolerated and has activity in nonsmall-cell lung cancer and other solid tumors: results of a phase I trial. J Clin Oncol 20: 3815-3825

Inoue A, Saijo Y, Maemondo M, Gomi K, Tokue Y, Kimura Y, Ebina M, Kikuchi T, Moriya T, Nukiwa T (2003) Severe acute interstitial pneumonia and gefitinib. Lancet 361: $137-139$

Janne PA, Gurubhagavatula S, Lucca J, Ostler P, Skarin AT, Fidias P, Lynch TJ, Johnson BE (2003) Clinical benefits in patients with advanced non small-cell lung cancer treated with gefitinib ('Iressa', ZD1839) in the compassionate use program. Lung Cancer 41(Suppl 2): S71 (abs O-243)

Kies MS, Arquette MA, Nabell L, Quinn D, Shin D, Needle MN, Waksal H, Hong WK, Herbst RS (2002) Final report of the efficacy and safety of the anti-epidermal growth factor antibody Erbitux (IMCC225), in combination with cisplatin in patients with recurrent squamous cell carcinoma of the head and neck (SCCHN) refractory to cisplatin containing chemotherapy. Proc Am Soc Clin Oncol 21: 232a (abs 925)

Kris MG, Natale RB, Herbst RS, Lynch Jr TJ, Prager D, Belani CP, Schiller JH, Kelly K, Spiridonidis H, Sandler A, Albain KS, Cella D, Wolf MK, Averbuch SD, Ochs JJ, Kay AC (2003) Efficacy of gefitinib (ZD1839, Iressa $^{\mathrm{TM}}$ ), an inhibitor of the epidermal growth factor receptor tyrosine kinase, in symptomatic patients with non-small cell lung cancer. A randomized trial. JAMA 22: 2149-2158

López Martin A, Constenla M, Martín Algarra S, Salinas P, Massuti B, Gascón P, Castellano D, López-Picazo JM, Rosell R, Cortés-Funes H (2003) Gefitinib ('Iressa', ZD1839) in advanced non-small-cell lung cancer patients after progression on chemotherapy. Poster presented at the ASCO. Chicago, IL, USA May 31 -June 3. Poster number 2695
Nakagawa K, Tamura T, Negoro S, Kudoh S, Yamamoto N, Yamamoto N, Takeda K, Swaisland H, Nakatani I, Hirose M, Dong R-P, Fukuoka M (2003) Phase I pharmacokinetic trial of the selective oral epidermal growth factor receptor tyrosine kinase inhibitor gefitinib ('Iressa' ZD1839) in Japanese patients with solid malignant tumours. Ann Oncol 14: $922-930$

Park J, Park B-B, Lee S-H, Park SH, Lee K-E, Lee SI, Nam E, Park JO, Lim YH, Park K (2003) Gefitinib ('Iressa', ZD1839) monotherapy as a salvage regimen for previously treated advanced non-small-cell lung cancer (NSCLC). Lung Cancer 41(Suppl 2): S249 (abs P-620)

Perez-Soler R, Chachoua A, Huberman M, Karp D, Rigas J, Hammond L, Rowinsky E, Preston G, Ferrante KJ, Allen LF, Nadler PI, Bonomi P (2001) A phase II trial of the epidermal growth factor receptor (EGFR) tyrosine kinase inhibitor OSI-774, following platinum-based chemotherapy, in patients (pts) with advanced, EGFR-expressing, non-small cell lung cancer (NSCLC). Proc Am Soc Clin Oncol 20: 310a (abs 1235)

Ranson M, Hammond LA, Ferry D, Kris M, Tullo A, Murray PI, Miller V, Averbuch S, Ochs J, Morris C, Feyereislova A, Swaisland H, Rowinsky EK (2002) ZD1839, a selective oral epidermal growth factor receptor-tyrosine kinase inhibitor, is well tolerated and active in patients with solid, malignant tumors: results of a phase I trial. J Clin Oncol 20: $2240-2250$

Rebattu P, Quantin X, Ardiet C, Morere J-F, Azarian M-R, Schuller-Lebeau M-P, Pujol J-L (2001) Dose-finding, pharmacokinetic and phase II study of docetaxel in combination with gemcitabine in patients with inoperable non-small cell lung cancer. Lung Cancer 33: 277-287

Rowinsky EK (2000) The pursuit of optimal outcomes in cancer therapy in a new age of rationally designed target-based anticancer agents. Drugs 60(Suppl 1): $1-14$

Schiller JH, Harrington D, Belani CP, Langer C, Sandler A, Krook J, Zhu J, Johnson DH, The Eastern Cooperative Oncology Group (2002) Comparison of four chemotherapy regimens for advanced non-smallcell lung cancer. $N$ Engl J Med 346: $92-98$

Soto Parra H, Cavina R, Zucali P, Campagnoli E, Latteri F, Biancofiore G, Abbadessa G, Morenghi E, Santoro A (2003) Gefitinib in elderly patients with progressive, pretreated, non-small-cell lung cancer: results from the Istituto Clinico Humanitas. Poster presented at the 10th WCLC Vancouver, Canada, August 10-14.

Thomas AL, Cox G, Sharma RA, Steward WP, Shields F, Jeyapalan K, Muller S, O'Byrne KJ (2000) Gemcitabine and paclitaxel associated pneumonitis in non-small cell lung cancer: report of a phase I/II doseescalating study. Eur J Cancer 36: 2329-2334

Willner J, Schmidt M, Kirschner J, Lang S, Borgmeier A, Huber RM, Flentje M (2001) Sequential chemo- and radiochemotherapy with weekly paclitaxel $\left(\right.$ Taxol $^{\mathbb{R}}$ ) and $3 \mathrm{D}$-conformal radiotherapy of stage III inoperable non small cell lung cancer. Results of a dose escalation study. Lung Cancer 32: $163-171$ 